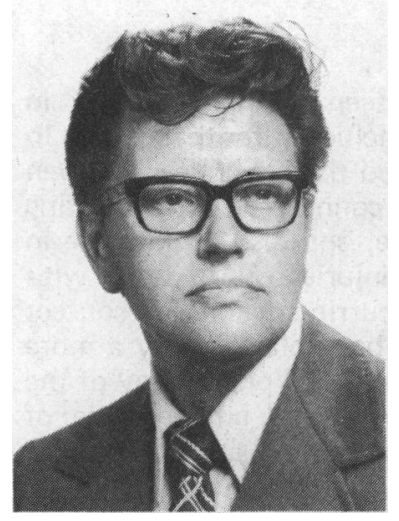

O. Sortland

Brit. J. Sports Med. - Vol. 16, No. 2, June 1982, pp. 80-84

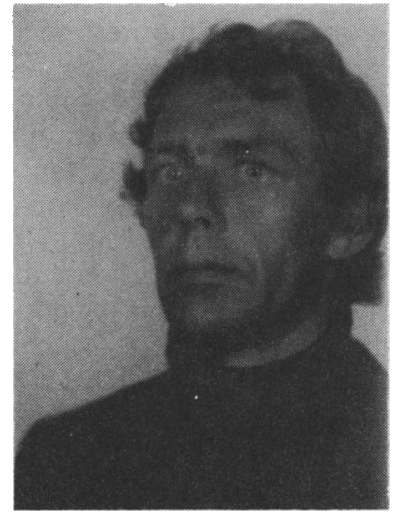

A. Tysvaer

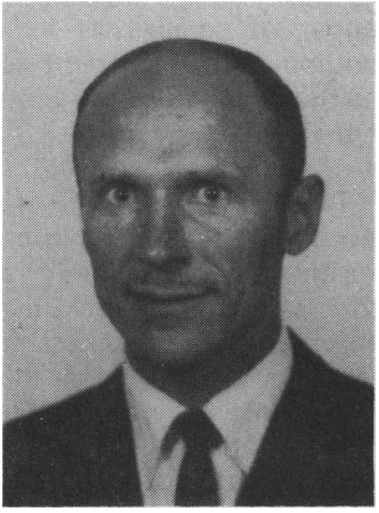

O. Storli

\title{
CHANGES IN THE CERVICAL SPINE IN ASSOCIATION FOOTBALL PLAYERS
}

\author{
O. SORTLAND, A. T. TYSVAER and O. V. STORLI
}

Rikshospitalet, University Hospital, Oslo, Norway

\begin{abstract}
Forty-three former players for the National Football Team of Norway were examined clinically and radiologically for degenerative changes in the cervical spine. Compared with men of the same age groups the onset of degeneration was 10-20 years earlier and the frequency of degeneration was significantly higher. Degenerative changes were not especially high in "headers", but this group had a higher frequency of subjective complaints and clinical findings such as reduced cervical movements.
\end{abstract}

Key words: Association football, neck, degenerative changes.

\section{INTRODUCTION}

Acute trauma resulting from sport is well known and football is in European countries responsible for the highest number of accidents. According to Axelsson, Renstrom et al (1980) $47 \%$ of sport injuries in males resulted from football. As reported by Roaas and Nilsson (1979) head and neck injuries amount to $22 \%$ of the total and approximately $9 \%$ of fractures. Serious neck injuries with permanent sequelae, rather frequent in American football (Torg et al, 1978), have been described only in a few cases in connection with association football.

Surprisingly few reports deal with late sequelae resulting from sport. Early degenerative changes in the lumbar spine of weight-lifters have been described by Kotani et al (1971-72) and Aggrawal et al (1979). Early osteoarthritis especially of the knees and ankles in footballers is reported by some authors (Adams, 1976). We have been unable to find any study concerning late sequelae of the cervical spine in football players.

\section{MATERIAL AND METHOD}

This study is based upon radiological and clinical examination of $\mathbf{4 3}$ footballers, all of them former players of the National Football Team of Norway. The players have on average participated in 26 (range 2-104) international games between Norway and other countries and in 326 (range 120-626) games in Norwegian First and Second division. Twelve of the players regarded themselves as "headers".

For comparison 43 men of the same age group were chosen from different occupational groups and none had a history of serious neck trauma.

Age distribution and average age of the footballers and of the comparison group appear in Table $\mathrm{I}$.

The X-ray examination of both groups included antero-posterior and open mouth views, lateral view of neutral, flexion and extension positions and oblique views. The films were examined especially with regard 
TABLE I

Age distribution (years)

$\begin{array}{lccccc} & 30-39 & 40-49 & 50-59 & 60-69 & \text { Average age } \\ \begin{array}{l}\text { Footballers } \\ \begin{array}{c}\text { Control } \\ \text { group }\end{array}\end{array} & 5 & 16 & 17 & 5 & 49.8 \\ & 5 & 14 & 19 & 5 & 50.2\end{array}$

to spinal axis, subluxations, healed fractures and degenerative changes. The finding of degenerative changes was observed in the upper or lower cervical region without regard to side. The upper cervical region was defined as the 4 most cranial segments including the intervertebral disc C4-C5, and the uncovertebral and intervertebral joints at the same level. The remaining 3 segments represented the lower cervical region.

The uncovertebral joints are small synovial joints on either side of the invertebral discs in the cervical vertebrae, described by J. E. Frazer in "The Anatomy of the Human Skeleton" as the neuro-central synovial cavity. They are regarded as of little clinical importance generally, but following degeneration with osteophyte formation they are of the greatest importance in cervicobrachial pain.

The degenerative changes were graded in the following manner:

Grade 1 - none or very slight changes.

Grade 2 - moderate degenerative changes, including degeneration of discs with moderate osteophyte formation.

Grade 3 - more pronounced degenerative changes with osteophytes measuring more than $3 \mathrm{~mm}$, uncovertebral osteophytes or osteophytes in the intervertebral joints protruding at least to the midline of the intervertebral foramina.

The grading in each level, upper and lower cervical regions, was registered for discs, uncovertebral joints and intervertebral joints, totally 6 figures in each person. The gradings were used as a score indicating the degree of degeneration. An average score was calculated for each level and structure in each age group. These average scores were added to a sum level score for each level and structure. For each decade all $\mathbf{6}$ average scores were added to a total average score for all footballers in general, "headers", "non headers", and for "control" (Table II and III).

The chi-square test was used for statistical calculations of the results.

\section{RESULTS}

In both groups, the footballers and the comparison

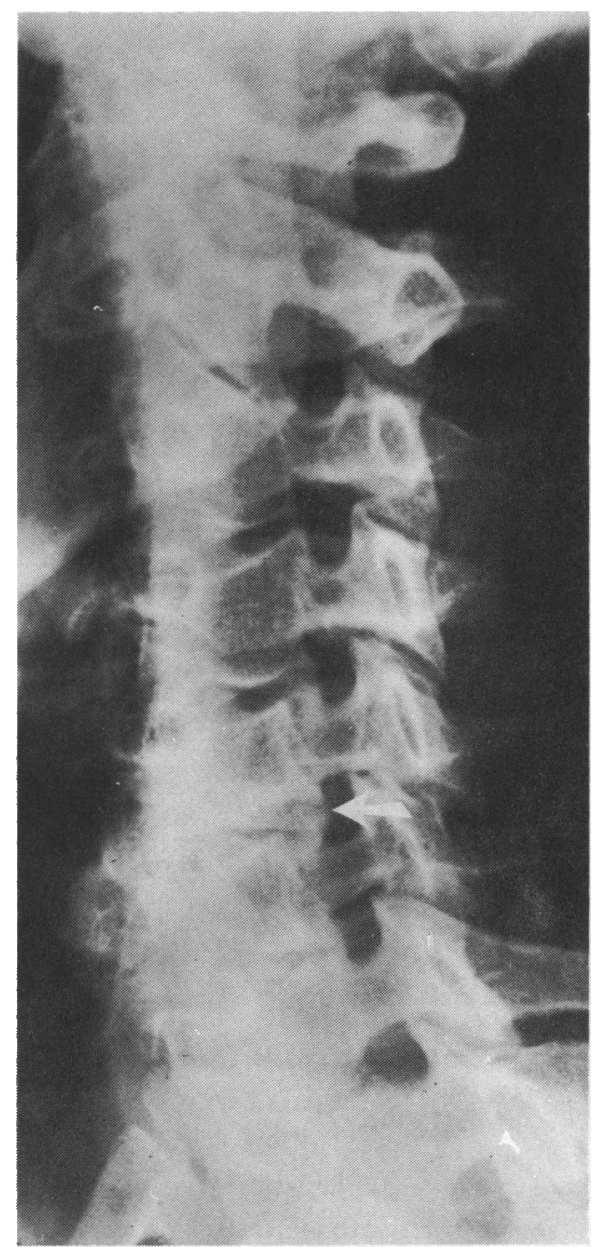

Fig. 1. Degeneration of grade 2 with moderate osteophyte (arrow) at the level of the fifth disc. Grade 1 at the level of the fourth disc. Normal intervertebral foramen at the level of the third disc.

group, the most pronounced degenerative changes were found in the lower cervical region affecting discs and uncovertebral joints. As can be seen from Table II the sum of level scores in all levels was higher in the footballers than in the control group. The greatest difference in the degree of degeneration between the footballers and the control group was seen in the intervertebral joints in the upper cervical region. The presence of degenerative changes and the frequency of grade 3 in this location were increased significantly in the footballers $(P<0.02, P<0.02)$. The corresponding figures in the intervertebral joints in the lower cervical region were also significantly different $(P<0.01, P<0.02)$. $A$ rather marked difference was also seen between the 2 groups concerning discs and uncovertebral joints in the lower cervical region. The differences with these locations were, however, not significant. 


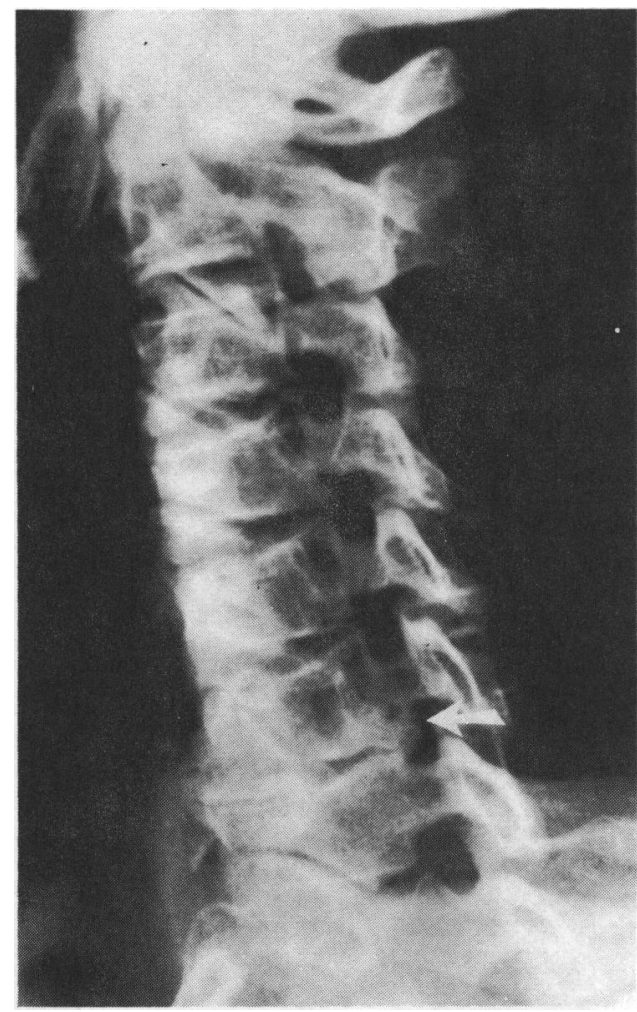

Fig. 2. Degeneration of grade 3 with large osteophyte (arrow) at the level of the sixth disc.

\section{TABLE ॥}

Average scores for footballers (F) and control group (C) for each level (upper/lower cervical) and structure: Discs (D), uncovertebral joints (UJ) and intervertebral joints (IJ). Sum level scores and total average scores calculated.

\begin{tabular}{|c|c|c|c|c|c|c|c|c|c|c|}
\hline \multirow{2}{*}{$\begin{array}{l}\text { Age (years) } \\
\text { D }\end{array}$} & \multicolumn{2}{|c|}{$30-39$} & \multicolumn{2}{|c|}{$40-49$} & \multicolumn{2}{|c|}{$50-59$} & \multicolumn{2}{|c|}{$60-69$} & \multicolumn{2}{|c|}{$\begin{array}{l}\text { Sum leve } \\
\text { scores }\end{array}$} \\
\hline & $\begin{array}{l}\mathrm{F} \\
\mathrm{C}\end{array}$ & $\begin{array}{l}1.0 \\
1.0\end{array}$ & $\begin{array}{l}\mathrm{F} \\
\mathrm{C}\end{array}$ & $\begin{array}{l}1.1 \\
1.1\end{array}$ & $\begin{array}{l}\mathrm{F} \\
\mathrm{C}\end{array}$ & $\begin{array}{l}1.4 \\
1.2\end{array}$ & $\begin{array}{l}\mathrm{F} \\
\mathrm{C}\end{array}$ & $\begin{array}{l}1.8 \\
1.4\end{array}$ & $\begin{array}{l}\mathrm{F} \\
\mathrm{C}\end{array}$ & $\begin{array}{l}5.3 \\
4.7\end{array}$ \\
\hline UJ & $\begin{array}{l}\mathrm{F} \\
\mathrm{C}\end{array}$ & $\begin{array}{l}1.4 \\
1.2\end{array}$ & $\begin{array}{l}F \\
C\end{array}$ & $\begin{array}{l}1.4 \\
1.4\end{array}$ & $\begin{array}{l}\mathrm{F} \\
\mathrm{C}\end{array}$ & $\begin{array}{l}1.7 \\
1.4\end{array}$ & $\begin{array}{l}\mathrm{F} \\
\mathrm{C}\end{array}$ & $\begin{array}{l}1.8 \\
1.6\end{array}$ & $\begin{array}{l}\mathrm{F} \\
\mathrm{C}\end{array}$ & $\begin{array}{l}6.3 \\
5.6\end{array}$ \\
\hline IJ & $\begin{array}{l}\mathrm{F} \\
\mathrm{C}\end{array}$ & $\begin{array}{l}2.0 \\
1.0\end{array}$ & $\begin{array}{l}\mathrm{F} \\
\mathrm{C}\end{array}$ & $\begin{array}{l}1.5 \\
1.3\end{array}$ & $\begin{array}{l}\mathbf{F} \\
\mathrm{C}\end{array}$ & $\begin{array}{l}1.8 \\
1.4\end{array}$ & $\begin{array}{l}\mathrm{F} \\
\mathrm{C}\end{array}$ & $\begin{array}{l}2.6 \\
1.8\end{array}$ & $\begin{array}{l}\mathrm{F} \\
\mathrm{C}\end{array}$ & $\begin{array}{l}7.9 \\
5.5\end{array}$ \\
\hline D & $\begin{array}{l}\mathrm{F} \\
\mathrm{C}\end{array}$ & $\begin{array}{l}1.4 \\
1.0\end{array}$ & $\begin{array}{l}\mathrm{F} \\
\mathrm{C}\end{array}$ & $\begin{array}{l}1.8 \\
1.3\end{array}$ & $\begin{array}{l}\mathrm{F} \\
\mathrm{C}\end{array}$ & $\begin{array}{l}2.2 \\
1.8\end{array}$ & $\begin{array}{l}\mathrm{F} \\
\mathrm{C}\end{array}$ & $\begin{array}{l}2.8 \\
2.2\end{array}$ & $\begin{array}{l}\mathrm{F} \\
\mathrm{C}\end{array}$ & $\begin{array}{l}8.2 \\
6.3\end{array}$ \\
\hline UJ & $\begin{array}{l}\mathrm{F} \\
\mathrm{C}\end{array}$ & $\begin{array}{l}1.6 \\
1.2\end{array}$ & $\begin{array}{l}\mathrm{F} \\
\mathrm{C}\end{array}$ & $\begin{array}{l}1.9 \\
1.4\end{array}$ & $\begin{array}{l}\mathrm{F} \\
\mathrm{C}\end{array}$ & $\begin{array}{l}2.1 \\
2.0\end{array}$ & $\begin{array}{l}\mathrm{F} \\
\mathrm{C}\end{array}$ & $\begin{array}{l}2.8 \\
2.4\end{array}$ & $\begin{array}{l}\mathbf{F} \\
\mathrm{C}\end{array}$ & $\begin{array}{l}8.4 \\
7.0\end{array}$ \\
\hline IJ & $\begin{array}{l}\mathrm{F} \\
\mathrm{C}\end{array}$ & $\begin{array}{l}2.0 \\
1.0\end{array}$ & $\begin{array}{l}\mathrm{F} \\
\mathrm{C}\end{array}$ & $\begin{array}{l}1.4 \\
1.1\end{array}$ & $\begin{array}{l}\mathrm{F} \\
\mathrm{C}\end{array}$ & $\begin{array}{l}1.8 \\
1.4\end{array}$ & $\begin{array}{l}\mathrm{F} \\
\mathrm{C}\end{array}$ & $\begin{array}{l}2.2 \\
1.8\end{array}$ & $\begin{array}{l}\mathrm{F} \\
\mathrm{C}\end{array}$ & $\begin{array}{l}7.4 \\
5.3\end{array}$ \\
\hline $\begin{array}{l}\text { Total } \\
\text { average } \\
\text { scores }\end{array}$ & $\begin{array}{l}\mathrm{F} \\
\mathrm{C}\end{array}$ & $\begin{array}{l}9.4 \\
6.4\end{array}$ & $\begin{array}{l}\mathrm{F} \\
\mathrm{C}\end{array}$ & $\begin{array}{l}9.1 \\
7.6\end{array}$ & $\begin{array}{l}\mathrm{F} \\
\mathrm{C}\end{array}$ & $\begin{array}{r}11.0 \\
9.2\end{array}$ & $\begin{array}{l}\mathrm{F} \\
\mathrm{C}\end{array}$ & $\begin{array}{l}14.0 \\
11.2\end{array}$ & & \\
\hline
\end{tabular}

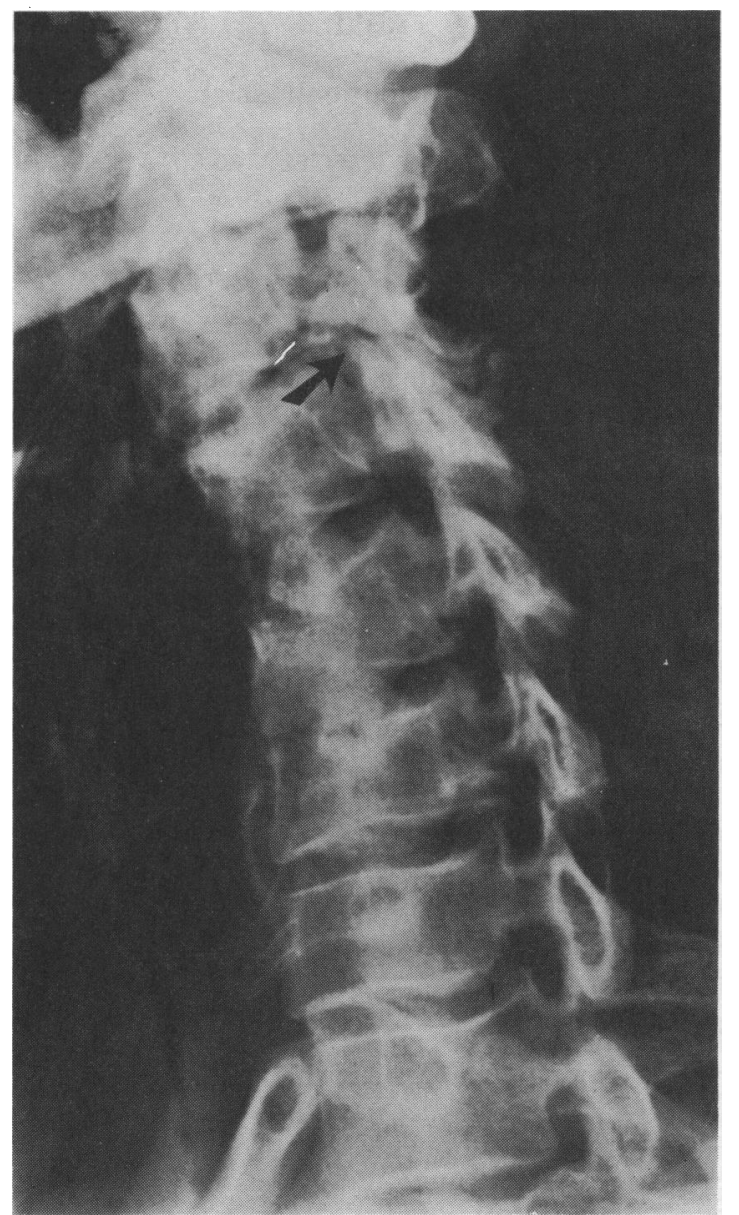

Fig. 3. Degeneration of grade 3 with considerable intervertebral arthrosis and large osteophyte (arrow) at the level of the third disc.

\section{TABLE III}

Total average scores in each decade of different groups.

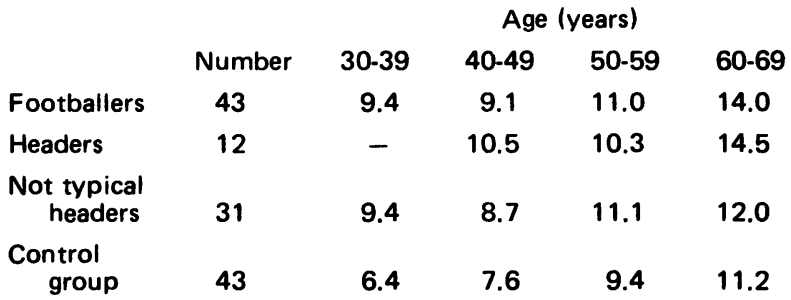

The total average scores showed both in the footballers and in the control group an increase with increasing age. The scores were in all decades higher in the footballers than in the control group (Fig. 4). The 


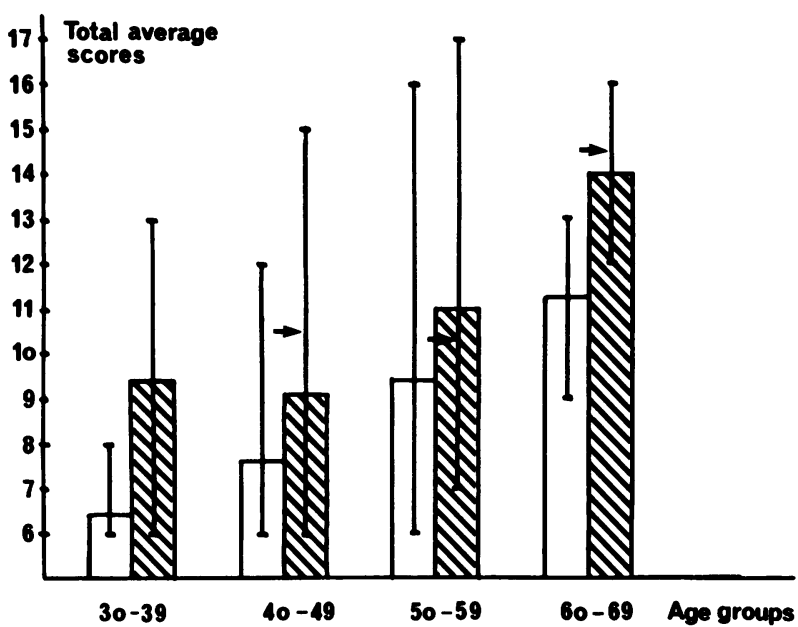

Total average scores of degeneration and range in footballers (hatched bars), control group (open bars), and headers $\rightarrow$.

figures showed a greater incidence in the footballers than in the control group, but in each decade these were more pronounced degenerative changes in the footballers. The total average score for each decade was also calculated separately in "headers" and "non headers", Table III. Slightly higher values were found in "headers", but the differences were small and not significant.

Slight or moderate scoliosis was found in 14 footballers and in 16 of the control group. Healed fractures were found in 5 footballers, in all players located to the lateral masses. In 3 players unilateral in the third vertebra, in one player bilateral in the fourth vertebra, and in one player bilateral in the sixth vertebra. Four out of 5 of those players were 57 years or older. In the control group one person had changes probably indicating an earlier fracture of the lateral mass of the sixth vertebra. Two footballers had moderate antero-lithisis at one level and the same was found in the control group.

A history of cervical complaints, pain and stiffness for years, was reported in 9 players $(21 \%)$ with a total average score of 11.4 and with an average age of 44 years. Five out of the 9 were "headers". Clinical examination revealed reduced motion of the cervical spine in $25(58 \%)$ of the players, markedly reduced in 18 of them. These 18 players had a total average score of 10.8 , but also an average age slightly above the mean. Ten out of 12 "headers" (83\%) were included in the 25 players with clinical findings. This preponderance of "headers" was, however, not significant $(P>0.05)$ probably due to small size of the sample. One out of 5 with healed fractures were in the group with complaints.

\section{DISCUSSION}

The results indicate an early development of degenerative changes in the cervical spine in footballers. As can be seen from Table II and Fig. 4, the onset of degenerative changes is 10 to 20 years earlier in footballers than in the control group. The final result also shows higher frequency and a more marked degree of the degenerative changes in the football players. The increased degeneration is especially located to the intervertebral joints and to the discs in the lower cervical spine.

The development of cervical spondylosis is dependent upon wear and tear. Footballers have multiple strains on their necks, maybe especially during heading, but also in other parts of the play. Movement may exceed the normal motility of the cervical spine causing lesions of the articulations, capsules and discs. The blow of heading is a hyper-extension and compression strain which may result in injury to the vertebral bodies, the intervertebral joints and the discs in the lower cervical region. It is of interest to point out that the fractures in 5 footballers were all compression fractures of the lateral masses. Four out of these 5 players were aged 57 years or more and osteoporosis is an unlikely factor in this group. These older footballers participated at a time when the game was played with a heavy all-leather ball which caused a much harder impact on heading, especially when wet, than the modern plastic ball.

In contradiction to what might be expected, the frequency and degree of spondylosis were not significantly increased in "headers", nor were the fractures limited to these players. Two fractures were found in 11 specialised headers of the ball, while the 3 other fractures were found in general players. This may be explained by a better heading technique in the "headers" resulting in less strain to the neck.

The frequency of subjective neck trouble and clinical findings were high amongst the players in general and in keeping with the radiological findings of a high incidence of degenerative changes. No especially severe degree of degeneration was found in the group with subjective complaints or in the group with clinical findings.

\section{REFERENCES}

Adams, I. D., 1976 "Osteoarthrosis and sport”. Clinics in Rheumatic Diseases 3: 523-541. 
Aggrawal, N. D., Kaur, R., Kumar, S. and Mathur, D. N., 1979 "A study of changes in the spine in weight-lifters and other athletes". Brit.J.Sports Med. 13: 58-61.

Axelsson, R., Renstróm, P. and Svensson, H.-O., 1980 “Akuta idrottsskador pa ett centrallasarett". Läkartidningen 41: 3615-3617.

Kotani, P. T., Ichikawa, N., Wakabayashi, W., Yoshii, T. and Koshimune, M., 1971-72 "Studies of spondylolysis found among weight-lifters"' Brit.J.Sports Med. 6: 4-8.

Roaas, A. and Nilsson, S., 1979 “Major injuries in Norwegian football”. Brit.J.Sports Med. 13: 3-5.

Torg, J. S., Trucx, R., Quedenfeld, T. C. Burstein, A., Spealman, A. and Nichols, C., 1978 "The national football head and neck injury registry". JAMA 241: 1477-1479.

\section{BOOK REVIEW}

Title: PSYCHOLOGY FOR PHYSIOTHERAPISTS (Psychology for Professional Groups)

Author: E. Naomi Dunkin

Editors: Antony Chapman and Anthony Gale

Publishers: The British Psychological Society and The MacMillan Press Ltd., 1981

Price: $£ 12.50$ (hard cover) ISBN $0333318579 . \quad £ 4.99$ (paper cover) ISBN 0333318846.

Psychology for Professional Groups is a new series of major textbooks published with the British Psychological Society. This book is one of the series, the principal aims of which are to illustrate how psychology can be applied in particular professional contexts, how it can improve the skills of practitioners, and how it can increase the practitioners' and students' understanding of themselves.

The Editor, Miss Naomi Dunkin has worked closely with two well-known teachers of physiotherapy in assembling this book, which is the first book on the subject written specifically for physiotherapists. Other experienced teachers and authorities of the BPS have written review chapters on key topics.

The book which is divided into four parts starts by defining scientific methodology in physiotherapy - it states a fact that we know well - the need for inter-professional communication of all members of the medical, para-medical and ancillary services, responsible for the care of the patient. Also that observation and accurate recording is a necessary habit, and how important it is that every member of the "team" should use the same methodology - with confidence and familiarity, and developing a total habit of questioning and searching for the real value of the things they do. This is a teaching book which covers all aspects of psychology that are relevant to the physiotherapists training and work.

With each chapter there is a list of references - annotated reading and questions which encourage the physiotherapist to enquire and seek for further knowledge. Each chapter continually reiterates - what, why, and when, things are done in order to explain the purpose of the body; to develop a fuller understanding of human life and identify human problems and to discover ways of reducing these as they are found.

Part I covers general issues. Methodology, motivation, learning, teaching, intelligence and perception. Part II deals with the individual, whereas Part III deals with social and time factors in life and finally Part IV takes the individual through various crises.

There is a great deal to read in this book. The Editors have carefully sifted the abundance of psychological literature to present material most interesting, valuable and available to the physiotherapist.

It encourages further reading and study, so is not only beneficial to the student, but also to the clinical physiotherapist, and therefore ultimately to the patient.

Margaret John, MCSP 